International Research Journal of Management, IT \& Social Sciences
Available online at https://sloap.org/journals/index.php/irjmis/
Vol. 6 No. 3, May 2019, pages: $94 \sim 100$
ISSN: 2395-7492
https://doi.org/10.21744/irjmis.v6n3.637

\title{
Influence of Mind Mapping Method Implementation on Learning Results Social Science is Required from Students Interest
}

Dewa Nyoman Wija Astawa ${ }^{a}$

Article history:

Received: 18 December 2018

Accepted: 31 March 2019

Published: 23 May 2019

\section{Keywords:}

achievement; learning interest; learning method; mind mapping; social science;

\begin{abstract}
This study aimed at investigating the effect of the implementation of mind mapping learning method to the students' social science achievement viewed from learning interest at the fourth-grade students of an elementary school in Denpasar city in the academic year 2016/2017. This study was quasiexperimental research which applied the posttest-only control group design involving 80 students of grade four at elementary school in Denpasar city who were selected by using the total sample sampling technique. The data of the students' social science achievement and learning interest were collected and then analyzed using the Analysis of Covariance (Anacova). The result of this study showed that the students' social science achievement who were treated with mind mapping learning method was higher compared to the students' social science achievement of those treated with the conventional learning method. This difference was consistent even though the students' learning interest has been controlled. Based on the result of this study, it is suggested that mind mapping learning method be applied in the teaching and learning process of social science at the elementary school.
\end{abstract}

2395-7492@ Copyright 2019. The Author. This is an open-access article under the CC BY-SA license (https://creativecommons.org/licenses/by-sa/4.0/) All rights reserved.

\section{Author correspondence: \\ Dewa Nyoman Wija Astawa, \\ IKIP Saraswati Tabanan, Indonesia. \\ Email address:dw.wija@gmail.com}

\section{Introduction}

Education is a basic effort to prepare students to face and anticipate people's lives in the future. Education also serves to prepare students to become members of the community who have the ability to make reciprocal relations with the social, cultural and natural environment and can develop further abilities in the world of work or higher education Winataputra (2002), In order to face and anticipate life in the future in front of human resources that have logical thinking, are creative, innovative, and have the ability to work effectively.

${ }^{\text {a }}$ IKIP Saraswati Tabanan, Indonesia 
Preparation efforts can be done through debriefing knowledge and various kinds of skills. In addition, the younger generation at the school level is very much needed to be provided with social knowledge, social values, and social skills so that they can struggle to live while developing their potential.

Hilda (2006), stated that "the aim of social studies education is to develop knowledge, attitudes, values, morals and a set of life skills in order to prepare good citizens who are capable of the community". Agreeing with that according to Lasmawan (2010), social studies education in elementary schools should be more emphasis on the elements of education and debriefing understanding, moral values, and social skills in students. So that someday they will be able to make what they have learned as a provision for themselves to continue their higher education.

Education in schools is only limited to transferring knowledge, not building the character of students, and students are not given the opportunity to reflect and position themselves in the education system which is solely for the benefit of the world of work. Reflection activities in education are very important, but reflection activities have now lost their place because education so far still shows a pattern of education that transfers knowledge. The competency curriculum has not yet led to character building and is still based on scientific disciplines.

The notion that social studies subjects are boring subjects is still embedded in their minds Romanda (2006), Many also consider that social study is an unattractive lesson, students do not get something that can be stored in their memories, it is difficult to remember enough material, and most students learn the material by memorizing. In addition, according to Lasmawan (2010), stated that phenomena encountered around social studies learning such as IPS is a subject that only contains facts, names and past events, learning only comes from textbooks, teachers cannot teach thinking skills, and teachers IPS departs a lot from the assumption that their job is to move the knowledge and skills that exist on them to the head of the student as a whole, or it can be said that the knowledge possessed by students is only memorizing Nurhadi et al., (2004). This is mostly due to the packaging of learning activities which are still dominated by conventional learning methods which emphasize lecturing in the delivery of subject matter.

The solution to avoiding social studies is less effective is to use a method or learning model that fits the conditions of students so that students can think critically, logically, and can solve problems with an open, creative, and innovative attitude. In learning known various learning methods one of which is Mind Mapping. According to Olivia (2008), found by Tony Buzan, it is a combination of creative thinking and active thinking. According to Tika (2012), "Mind mapping is a way of recording creative, effective, and mapping our thoughts, in an interesting, easy and efficient way". This method is relevant for early childhood (4 years) to the age of adults. Therefore, this method is deemed appropriate enough to be developed in social studies learning for 4th-grade elementary school students. Mind Mapp is a great organizational thought tool, a creative, effective way of writing, and literally going to map our thoughts very simply. All mind maps have similarities, namely by using colors and having natural structures that emanate from the center, using curved lines, symbols, words, and images that are compatible with how the brain works (Buzan, 2007).

Develop mind mapping to make it easier for students to learn social studies with fun, very relevant for elementary school students. The lessons are packaged using various images, colors, and students themselves who directly make it will make students better understand the subject matter delivered. According to Piaget in Suprijono (2009), states that elementary students are in a concrete operational phase, while the characteristics are: 1) imitating what they see, 2) liking tangible objects, and 3) understanding faster by doing directly.

Mind Mapping learning method brings the concept of innovative understanding and is expected to improve student learning outcomes. According to Agung (2005), learning outcomes are "results obtained by students after experiencing the learning process interaction". So improving learning outcomes is raising the results obtained by students through effort (experience and practice) in learning certain subjects that are experienced or designed.

In addition to the right learning method, students' learning interest in a lesson will also have an influence on student learning outcomes. According to Tidjan (2001), "interest is a psychological phenomenon that shows the concentration of attention on an object because there is a feeling of pleasure. From this understanding, it is clear that interest is as a concentration of attention or reaction to an object such as a particular object or a certain situation that is preceded by feelings of pleasure towards the object ". So that student interest in a lesson is very influential on student learning outcomes (Suparsa et al., 2017: Astawa et al., 2017: Subiyanto, 2016).

Based on the background of the problem, the purpose of this research is as follows. First, testing whether there are differences in social studies learning outcomes between students who follow the Mind Mapping learning method and students who follow conventional learning methods. Second, testing whether there are differences in social studies learning outcomes between students who follow the Mind Mapping learning method and students who follow conventional learning methods, after the covariable interest in learning is controlled. Third, determine the contribution of an interest in social studies learning outcomes to fourth-grade students in Denpasar.

Astawa, D. N. W. (2019). Influence of mind mapping method implementation on learning results social science is required from students interest. International Research Journal of Management, IT and Social Sciences, 6(3), 94-100. https://doi.org/10.21744/irjmis.v6n3.637 


\section{Materials and Methods}

This research is a quasi-experiment designed using the design of the posttest-only control group design. In this experiment divided into two groups. The first group was subjected to treatment with the Mind Mapping learning method, while the second group was subjected to treatment with conventional learning methods. The population of this study was fourth-grade students of an elementary school in Denpasar in 2016/2017, amounting to 80 people. The sample in this study was taken using a total sample of classes, where each of the experimental and control classes amounted to 40 people. The variables in this study can be divided into three, Mind Mapping learning methods are independent variables, IPS learning outcomes as dependent variables and student learning interests act as covariables or controlling variables.

In connection with the research conducted, the data needed is a score of social studies learning outcomes collected through social studies learning outcomes tests, while for learning interest is collected through filling out questionnaires with a Likert scale pattern. After the data collected, data analysis was performed using anacova statistics.

In this study, there are three hypotheses that will be reviewed. First, there are differences in social studies learning outcomes between students who follow the Mind Mapping learning method and students who take learning using conventional methods. Second, there are differences in social studies learning outcomes between students who follow the Mind Mapping learning method and students who follow learning with conventional methods, after interest in learning is controlled. Third, there is a positive and significant contribution between the interests and learning outcomes of social studies in fourth-grade students in Denpasar.

\section{Results and Discussions}

The first hypothesis, the results of the first hypothesis test states that, social studies learning outcomes of fourthgrade elementary school students in Denpasar who follow the Mind Mapping learning method are better than students who follow conventional learning methods. This is indicated by the coefficient (F) of 20.50 which turns out to be significant. Furthermore, based on statistical calculations, it was found that social studies learning outcomes of students who followed the Mind Mapping learning method had an average score of 73.05 higher than the social studies learning outcomes of students who followed conventional learning methods that had an average score of 60.63 . This proves that the Mind Mapping learning method is superior and suitable to be applied to students, rather than conventional learning methods. The application of the Mind Mapping learning method has advantages such as (1) activating the entire brain, allowing us to focus on the subject, (2) helping to show the relationship between the separate parts of information, (3) giving a clear picture of the whole and details, and (4) fun to see, read, digest and remember. Moreover, in terms of the characteristics of elementary school students belonging to the concrete operational phase. They are easier to understand something through media that can attract their learning interest. So that learning outcomes will be more meaningful for students, because they work, think and experience the learning process themselves. In the Mind Mapping learning method there are several main steps in the implementation, such as: (1) the teacher gives the main topic of the material provided, (2) students prepare a blank piece of paper (in a horizontal position) without lines and some color pens to make an image that summarizes the main subject in the middle of the paper, (3) students make thick squiggly lines that connect from the image in the middle of the paper, each for each main idea that exists about the subject, (4) students give names to each of the ideas above. You can also add small pictures of each of these ideas, this uses both sides of the brain, (5) from each of the ideas, draw another connecting line, which spreads like tree branches. Add thoughts to each of these ideas. These additional branches represent the details, (6) the teacher draws conclusions with the students.

When compared with conventional learning methods, the Mind Mapping learning method emphasizes student involvement in learning, students become more actively involved in the learning process and assessment for decision making. Students will no longer feel that social studies learning is a memorizing, boring and meaningless lesson. This is also reinforced according to curriculum guidelines which state that student learning experience occupies an important position in an effort to improve the quality of graduates. Meanwhile, more conventional learning uses the lecture method in learning, so it is difficult to develop students' thinking skills to solve and make decisions. With more communication styles than one person, the opportunity to control students' ability to understand learning material is very limited. As from the implications of conventional learning students become accustomed to accepting whatever is given by the teacher without trying to find the concepts themselves that are being studied, students have less opportunity to be involved in the learning process. this is what causes students to be bored to receive the lessons given. 
In the end, it will lead to the lack of optimal competencies that students have so that the learning outcomes obtained are less than optimal.

The second hypothesis, the results of the second hypothesis test states that, with the control of interest held, the results of social studies learning students who follow the Mind Mapping learning method are still better with social studies learning outcomes of students who follow conventional learning methods. It turned out that the results of anacova's analysis found $(F)=30.27$. This means that there is an increase in differences in social studies learning outcomes. This means that interest also affects social studies learning outcomes. Furthermore, the third hypothesis shows that the contribution of the Mind Mapping learning method to student social studies learning outcomes is $21.44 \%$, social studies learning outcomes of students who follow the conventional learning method are $20.65 \%$ and together the learning outcomes of students who follow the Mind Mapping learning method and students who followed the conventional learning method amounted to $23.23 \%$.

Based on the contribution data above, it can be seen that the influence of student interest in social studies learning outcomes is quite large if we take into account the other effects of learning outcomes which are quite a lot other than interests.

Thus, the implication for a teacher, especially an elementary teacher who teaches social studies subjects, should pay attention to student learning interests, because with students interested in social studies will have a positive impact on the learning outcomes obtained. Student interest can be grown if students feel interested, and feel they need something related to things that are often faced by students. Besides that, through the learning process by applying the Mind Mapping learning method that is able to create a fun, interesting atmosphere, activate students, involve students and give students to create themselves according to their wishes. This will arouse student interest in social studies. However, on the contrary, if the learning method applied by the teacher is less challenging for students, then the interest of students to take part in the social studies learning process will actually decrease. So that the learning outcomes obtained are also not maximal. So, the Mind Mapping learning method is able to arouse student learning interest. With the application of these learning methods, undoubtedly the results of students' social studies are better.

\section{Conclusion}

Based on the analysis of the data described earlier, this study has proven that learning using the Mind Mapping learning method has a better effect on social studies learning outcomes, both before and after the control of the interest in learning is held.

The conclusion of this study is that the Mind Mapping learning model can improve social studies learning outcomes of fourth-grade students in Denpasar. The findings are as follows. (1) This study proves that social studies learning outcomes of students who follow the Mind Mapping learning method differ significantly from the learning outcomes of students who take conventional learning. This can be seen from the Analysis of Variance on learning outcomes indicating that found the price of Fcount $=20.50$ this price is significant at the level of 5\%. Furthermore, it can be seen that the social studies learning outcomes of students who take the Mind Mapping learning method differ from the ability of social studies learning outcomes of students who follow conventional learning methods. The average score of social studies learning outcomes of students who take the Mind Mapping learning method is 73.05 while the average score of learning outcomes of students who follow the conventional learning method is 60.63 (2) After controlling for interest in learning, $\mathrm{F}=30$ is obtained. 27 this price is significant at the level of 5\%. Thus it can be concluded that after controlling for interest in learning there is a significant difference in the results of social studies learning students who take the Mind Mapping learning method with social studies learning outcomes of students who take conventional learning. (3) The magnitude of the influence given by the controlling variable to the social studies learning outcomes is evident in its effective contribution. Interest contribution to social studies learning outcomes for students who followed the Mind Mapping learning method was $21.44 \%$. While the contribution of an interest in social studies learning outcomes in students who follow the conventional learning method is $20.65 \%$. The small contribution of an interest in social studies learning outcomes because so far social studies lessons are only presented with less innovative methods to students. However, the results of this test indicate that there is a positive contribution of an interest in social studies learning outcomes both to students who follow the Mind Mapping method or to students who follow conventional learning methods.

Astawa, D. N. W. (2019). Influence of mind mapping method implementation on learning results social science is required from students interest. International Research Journal of Management, IT and Social Sciences, 6(3), 94-100. https://doi.org/10.21744/irjmis.v6n3.637 
Suggestions

Some suggestions that can be put forward related to this research are as follows. First to students, (1) Students are expected to have a high interest in learning in receiving a subject matter, this will have a positive impact on student learning outcomes themselves. (2) In addition, students should be active in conducting the learning process, so students are accustomed to communicating, independent learning in dealing with a problem at hand. Later students will be able to apply it directly to their wider social environment. Second to the teacher, (1) This study shows that social studies learning outcomes of students who follow the Mind Mapping learning method are different from the social studies learning outcomes of students who take conventional learning. For that, the Mind Mapping learning method needs to be introduced and developed further to teachers, students and other education practitioners as an alternative learning. The introduction process can be done with social studies learning seminars or seminars. (2) Further research related to Mind Mapping learning needs to be done with reading material and other subjects by involving a wider sample. (3) With the positive contribution of an interest in social studies learning outcomes both to students who follow the Mind Mapping learning method and to students who follow conventional learning methods, the teacher is expected to always train and assess student interest in learning to improve student learning outcomes. Third to schools, (1) Schools should pay attention to teachers who have creativity in the learning process. There are many ways that can be done to give appreciation to the teacher's performance, such as direct thank-you, charter, and others. Thus other teachers will be motivated to work in increasing creativity in teaching. So that later it will have a positive impact on learning outcomes themselves. (2) Schools should facilitate teachers in providing and developing creative and innovative learning methods. Like for example by setting up LCDs, projectors, and others. So that it makes it easier for teachers to develop their creativity.

Conflict of interest statement and funding sources

The author declared that they have no competing interest. The study was financed by personal funding.

Statement of authorship

The author has a responsibility for the conception and design of the study. The author has approved the final article.

\section{Acknowledgments}

I express my thankfulness to the Almighty God who has granted me this chance and ability to finish this article. My thanks also go to my friends who contributed to my research. I especially express my gratitude to Prof. Dr. I Wayan Suastra, M.Pd. who gave me advice and motivation for my personal development. Without their words and supports this cannot be here. This article may be found meaningful to the readers. 


\section{References}

Agung, A. A. (2011). Metodologi Penelitian Pendidikan Suatu Pengantar. Singaraja: Fakultas Ilmu Pendidikan Undiksha Singaraja.

Astawa, I. N., Handayani, N. D., Mantra, I. B. N., \& Wardana, I. K. (2017). Writing English language test items as a learning device: a principle of habit formation rules. International Journal of Social Sciences and Humanities, 1(3), 135-144. https://doi.org/10.29332/ijssh.v1n3.67

Buzan, T. (2006). Buku pintar mind map. Gramedia Pustaka Utama.

Karli, H. (2014). Perbedaan Kurikulum Tingkat Satuan Pendidikan 2006 dan Kurikulum 2013 untuk Jenjang Sekolah Dasar. Jurnal Pendidikan Penabur, 22(8), 84-96.

Lasmawan, W. (2010). Menelisik Pendidikan IPS dalam Perspektif Kontekstual-Empiris. Singaraja: Mediakom Indonesia Press Bali.

Nurhadi. (2004). Rekonstruksi Epistimologi Pendidikan IPS Sebagai Program Pendidikan (Isu, Kecenderungan, dan Komitmen). Bandung.

Olivia, F. (2008). Gembira Belajar dg Mind Mapping+ CD. Elex Media Komputindo.

Putra, U. S. W., \& Udin, S. (2002). Materi dan Pembelajaran IPS SD. Universitas.

Romanda, E.M. (2006). Penggunaan Metode Sas dalam Peningkatan Kemampuan Membaca Permulaan pada Siswa Kelas 1 SD Negeri Purwoyoso Semarang. (accessed on 12 September 2016).

Subiyanto, P. (2016). The impact of transposition on grammatical metaphor a study of translation from the perspective of SFL theory. International Journal of Linguistics, Literature and Culture, 2(3), 117-123.

Suparsa, I. N., Mantra, I. B. N., \& Widiastuti, I. A. M. S. (2017). Developing learning methods of Indonesian as a foreign language. International Journal of Social Sciences and Humanities, 1(2), 51-57. https://doi.org/10.29332/ijssh.v1n2.41

Suprijono, A. (2009). Cooperative learning: teori \& aplikasi PAIKEM. Pustaka Pelajar.

Tidjan. (2001). Evaluasi Pendidikan. Jakarta: Radja Grafindo Persada.

Tika, I.N. (2012). IPA SD. Singaraja.

Astawa, D. N. W. (2019). Influence of mind mapping method implementation on learning results social science is required from students interest. International Research Journal of Management, IT and Social Sciences, 6(3), 94-100. https://doi.org/10.21744/irjmis.v6n3.637 


\section{Biography of Author}

\begin{tabular}{||l|l|}
\hline & Dewa Nyoman Wija Astawa is a lecture in the IKIP Saraswati Tabanan and has a \\
functional level as a head lector. His registration of civil servant is \\
196511051991031002. He was born in Buleleng on November 5, 1965. His office is at \\
Jln. Pahlawan No. 2 Tabanan-Bali, Ph. +62361 814909, web: \\
www.ikipsaraswatitabanan.com, e-mail: ikipsaraswati@ yahoo.co.id. Graduated with a \\
Bachelor degree in 1990 at Udayana University. In 2001, he has finished his Master \\
Degree at UPI Bandung and the last, in 2018 he is completing his doctoral program at \\
Ganesha University of Singaraja (Undiksha). He is also a consultant in education and \\
Trainer of Education Human Values in Sathya Sai Education Institute of Indonesia. \\
Email: dw.wija@gmail.com \\
\hline
\end{tabular}

